\title{
FAKTOR-FAKTOR YANG BERPENGARUH TERHADAP PENERAPAN PROGRAM PERENCANAAN PERSALINAN DAN PENCEGAHAN KOMPLIKASI (P4K) DI KELURAHAN BALAI GADANG PADANG \\ Desi Sarli ${ }^{1)}$, Titin Ifayanti ${ }^{2}$ \\ ${ }^{1}$ Akademi Kebidanan Alifah Padang \\ email: desi_sarli@yahoo.com
}

\begin{abstract}
ABSTRAK
Diperkirakan 20\% kehamilan akan mengalami komplikasi. Tahun 2007 Menteri Kesehatan mencanangkan Program Perencanaan Persalinan dan Pencegahan Komplikasi (P4K) dengan stiker yang merupakan upaya terobosan mempercepatan penurunan angka kematian Ibu dan bayi baru lahir. Dari data DKK Padang tahun 2014 Puskesmas Air Dingin mempunyai penanganan komplikasi dengan angka tertinggi $(77,06 \%)$. Dari survey awal yang dilakukan terhadap $10 \mathrm{ibu}$ hamil terdapat $60 \%$ tidak menerapkan P4K. Tujuan dari penelitian ini yaitu mengetahui bagaimana penerapan P4K dan faktor apa saja yang mempengaruhinya. Jenis penelitian ini adalah penelitian Analitik dengan desain penelitian Cross Sectional Study. Penelitian dilakukan \pm 6 bulan. Populasi yaitu ibu hamil sebanyak 128 orang. Pengambilan sampel dengan teknik Total Sampling. Data diambil menggunakan kuisioner, dianalisa secara multivariat, dan diolah secara komputerisasi. Hasil penelitian menunjukkan dari 128 ibu hamil yang tidak menerapkan P4K sebanyak 66,4 \%, tingkat pengetahuan rendah sebanyak $18 \%$, peran keluarga rendah 57,8 \%, peran kader rendah 43,8 \%, peran bidan rendah $57,8 \%$. Terdapat hubungan yang bermakna antara tingkat pengetahuan, peran keluarga, peran bidan dengan penerapan P4K. Peran keluarga dan peran bidan mempengaruhi penerapan P4K memelui uji statistik secara multivariat. Berdasarkan hasil uji interaksi diketahui bahwa terdapat interaksi antara peran keluarga dan peran bidan dengan $p$ value $=0,003$. Dari hasil penelitian diketahui peran keluarga dan peran bidan mempengaruhi penerapan P4K. Diharapkan adanya suatu program yang memotivasi dan meningkatkan peran serta keluarga dalam merencanakan persalinan yang aman dengan menggalakan desa dan suami siaga dengan adanya penyuluhan untuk keluarga tentang P4K.
\end{abstract}

Kata Kunci: Pengetahuan, Peran Keluarga, Peran Kader, Peran Bidan, Penerapan P4K

\begin{abstract}
An estimated 20\% of pregnancies will experience complications. In 2007 the Ministry of Health launched the Programme Planning and Prevention Childbirth Complications (P4K) with a sticker which is a breakthrough effort mempercepatan reduction in the maternal mortality rate and the newborn. Data from 2014 DKK Puskesmas Air Dingin Padang has treatment of complications with the highest rate (77.06\%). From the initial survey conducted on 10 pregnant women are $60 \%$ does not apply P4K. The purpose of this research is to know how the application P4K and what factors influence it.This type of research is analytical research with cross sectional study design research. The research out for \pm 6 month. The population is pregnant women as many as 128 people. Sampling with total sampling technique. The data were taken using a questionnaire, multivariate analysis, and processed with computer.The results showed 128 pregnant women who do not menerapan P4K as much as 66.4\%, a low level of knowledge as much as $18 \%, 57.8 \%$ lower family role, the role of lower cadres 43.8\%, 57.8\% lower midwife's role. There is a significant relationship between the level of knowledge, the role of the family, the role of midwife to the application of P4K. The role of the family and the midwife's role P4K memelui affect the application of multivariate statistical tests. Based on the result of interaction is known that there is interaction between the role of the family and the role of the midwife with $p$ value $=0.003$.The survey results revealed the role of the family and the role of midwife affect the application P4K. It is hoped the presence of a program designed to motivate and increase the participation of families in planning for safe delivery by promoting the village and to stand by their husband's family about P4K counseling.
\end{abstract}

Keywords: Knowledge, The Role of Family, The Role of Cadres, The Role of Midwife, Implementation of $\mathrm{P} 4 \mathrm{~K}$ 


\section{PENDAHULUAN}

Anak dan Ibu merupakan dua anggota keluarga yang perlu mendapatkan prioritas dalam penyelenggaraan upaya kesehatan. Penilaian terhadap status kesehatan dan kinerja upaya kesehatan Ibu dan anak penting untuk dilakukan. Hal tersebut disebabkan Angka Kematian Ibu dan Anak merupakan dua indikator yang peka terhadap kualitas fasilitas pelayanan kesehatan. Kualitas fasilitas pelayanan kesehatan yang dimaksud termasuk aksesibilitas terhadap fasilitas pelayanan kesehatan itu sendiri. $^{1}$

Menurut World Health Organitation (WHO) tahun 2011 Angka Kematian Ibu (AKI) di negara-negara Asia Tenggara seperti Malaysia (29/100.000 kelahiran hidup), Thailand $(48 / 100.000 \mathrm{KH})$, Vietnam $(59 / 100.000 \mathrm{KH})$, serta Singapore (3/100.000 KH). Dibandingkan dengan negara-negara maju, angkanya sangat jauh berbeda seperti Australia $(7 / 100.000 \mathrm{KH})$ dan Jepang (5/100.000 KH).

Berdasarkan Survei Demografi dan Kesehatan Indonesia (SDKI) tahun 2012, AKI (yang berkaitan dengan kehamilan, persalinan, dan nifas) sebesar 359 per 100.000 kelahiran hidup. Rata-rata kematian ini jauh melonjak dibanding hasil SDKI tahun 2007 yang mencapai 228/100.000 kelahiran hidup. ${ }^{2}$

Sedangkan untuk kota Padang kasus kematian Ibu pada tahun 2013 bejumlah 15 kasus, turun jika dibanding tahun 2012, yaitu sebanyak 16 orang. Adapun rincian kematian Ibu ini terdiri dari kematian Ibu hamil 4 orang, kematian Ibu bersalin 5 orang dan kematian Ibu nifas 6 orang. Sementara jika dilihat berdasarkan umur, kurang dari 20 tahun tidak ada, 20 s/d 34 tahun sebanyak 11 orang dan diatas 34 tahun 4 orang. ${ }^{3}$

Menurut WHO (2010) sekitar 287.000 Ibu meninggal karena komplikasi kehamilan dan kelahiran anak, seperti perdarahan 28\%, preeklampsi/eklampsi 24\%, infeksi 11\%, dan penyebab tidak langsung (trauma obstetri) 5\%. Dan sebagian besar kasus kematian Ibu di dunia terjadi di negara-negara berkembang termasuk Indonesia (WHO, 2011). Dalam menyumbangkan AKI di Indonesia ada lima penyebab kematian Ibu terbesar adalah perdarahan, hipertensi dalam kehamilan (HDK), infeksi, partus lama/macet dan abortus. Kematian Ibu di Indonesia tetap didominasi oleh tiga penyebab utama kematian yaitu perdarahan, hipertensi dalam kehamilan (HDK), dan infeksi. Proporsi ketiga penyebab kematian Ibu telah berubah, dimana perdarahan dan infeksi cenderung mengalami penurunan sedangkan HDK proporsinya semakin meningkat. Lebih dari 30\% kematian Ibu di Indonesia pada tahun 2010 disebabkan oleh HDK.

Untuk menanggulangi masalah tersebut telah dilakukan upaya penurunan AKI. Pada tahun 2000 Departemen Kesehatan telah mencanangkan Strategi Making Pregnency Safer (MPS) yang merupakan strategi terfokus dalam penyediaan dan pemantapan pelayanan kesehatan dengan 3 (tiga) pesan kunci MPS: (1) Setiap persalinan ditolong oleh tenaga kesehatan terlatih, (2) Setiap komplikasi obstetri dan neonatal mendapat pelayanan yang adekuat, dan (3) Setiap wanita usia subur mempunyai akses terhadap pencegahan kehamilan yang tidak diinginkan dan penanganan komplikasi keguguran. Upaya penurunan AKI tersebut dilaksanakan melalui empat strategi, yaitu: (1) Peningkatan kualitas dan akses pelayanan kesehatan ibu dan bayi, (2) Kerjasama lintas program, lintas sektor terkait dan masyarakat termasuk swasta, (3) Pemberdayaan perempuan, keluarga, dan pemberdayaan masyarakat, dan (4) Meningkatkan surveilence, monitoring-evaluasi KIA dan pembiayaan (Pedoman P4K dengan Stiker Depkes RI, 2009).

Di masyarakat kita, seringkali perempuan tidak mempunyai akses dalam pemanfaatan pelayanan kesehatan dan kewenangan untuk memutuskan masalah kesehatannya sendiri. Sehubungan dengan hal tersebut dan sesuai dengan strategi MPS, upaya percepatan penurunan angka kematian ibu diperlukan adanya dukungan lintas sektor dalam pemberdayaan perempuan, keluarga, dan masyarakat dalam perencanaan persalinan dan kesiagaan dalam menghadapi komplikasi obsteri dan neonatal (Pedoman P4K dengan Stiker Depkes RI, 2009).

Pada tahun 2007 Menteri Kesehatan mencanangkan Program Perencanaan Persalinan dan Pencegahan Komplikasi (P4K) dengan stiker yang merupakan uapaya terobosan dalam percepatan penurunan angka kematian Ibu dan bayi baru lahir melalui kegiatan peningkatan akses dan kualitas pelayanan, yang sekaligus merupakan kegiatan yang membangun potensi masyarakat, khususnya kepedulian masyarakat untuk persiapan dan tindak dalam menyelamatkan Ibu dan bayi baru lahir (Pedoman P4K dengan Stiker Depkes RI, 2009).

Diperkirakan 20\% kehamilan akan mengalami komplikasi. Sebagian komplikasi ini dapat mengancam jiwa, tetapi sebagian besar komplikasi dapat dicegah dan ditangani bila : 1) Ibu segera mencari pertolongan ke tenaga kesehatan; 2) Tenaga kesehatan melakukan prosedur penanganan yang sesuai, antara lain penggunaan partograf untuk memantau perkembangan persalinan, dan pelaksanaan manajemen aktif kala III (MAK III) untuk mencegah perdarahan pasca-salin; 3) Tenaga kesehatan mampu 
melakukan identifikasi dini komplikasi; 4) Apabila komplikasi terjadi, tenaga kesehatan dapat memberikan pertolongan pertama dan melakukan tindakan stabilisasi pasien sebelum melakukan rujukan; 5) Proses rujukan efektif; 6) Pelayanan di RS yang cepat dan tepat guna (Profil Kesehatan RI, 2013).

Kegiatan P4K dengan Stiker keberhasilannya dipengaruhi oleh adanya peran serta aktif dari bidan, kader, serta keluarga yang dapat memberikan kontribusi untuk menyukseskan kegiatan P4K dalam rangka percepaan penurunan angka kematian Ibu dan bayi baru lahir. ${ }^{4}$

Berdasarka penelitian Rahmawati dan devi (2011) menunjukan bahwa mayoritas tingkat pengetahuan ibu hamil baik yaitu sebanyak 21 orang $(46,7 \%)$, sebagian besar ibu hamil menggunakan stiker P4K yaitu sebanyak 27 orang (60\%). Menurut penelitian Mikrajab dan Tety (2011) menunjukkan bahwa peran kader kesehatan yang telah dilaksanakan adalah pemeriksaan kehamilan telah mencapai $100 \%$; pemasangan stiker P4K telah mencapai 94,0\%; Penyimpanan buku KIA oleh Ibu hamil telah mencapai $88,1 \%$; penyuluhan pada dukun bayi baru mencapai $73,1 \%$; PWS bersama bidan baru mencapai 59,7\%; belum memberikan buku KIA kepada ibu hamil masih 25,4\%; dan merujuk ke Puskesmas mencapai $62,7 \% .^{5}$

Dalam hal penanganan komplikasi untuk kota Padang penanganan komplikasi kebidanan yang terjadi dengan angka tertinggi yaitu di wilayah kerja Pukesmas Air Dingin Padang (77,06 \%) dengan cakupan didistribusikan buku KIA sebesar 62,4\% pada tahun 2014. ${ }^{6}$

Berdasarkan survei awal yang dilakukan di Puskesmas Air Dingin jumlah Ibu hamil tahun 2015 sebanyak 535 orang (kelurahan Balai Gadang 247 orang, Air Pacah 156 orang, Lubuk Minturun 132 orang dengan jumlah komplikasi sebanyak 104 orang $(19.44 \%)$. Dari survey awal yang dilakukan terhadap 10 Ibu hamil di wilayah Balai Gadang didapatkan 6 Ibu hamil belum mengisi stiker P4K dan 2 orang diantaranya menempel stiker tanpa mengisi stiker P4K.

Berdasarkan uraian di atas peneliti bermaksud melakukan penelitian mengenai Faktor-Faktor yang Berpengaruh terhadap Penerapan Program PerencanaanPersalinan dan Pencegahan Komplikasi (P4K) di Kelurahan Balai Gadang wilayah kerja Puskesmas Air Dingin Padang Tahun 2016.

\section{METODE PENELITIAN}

Jenis penelitian yang dilaksanakan adalah penelitian Analitik dengan desain penelitian CrossSectional Study, yaitu dimana variabel independen (tingkat pengetahuan Ibu, peran keluarga, peran kader, peran bidan) serta variabel dependen(penerapan Perencanaan Persalinan dan Pencegahan Komplikasi (P4K)) dikumpulkan secara bersamaan. Populasi dari penelitian ini adalah semua Ibu hamil di Kelurahan Balai Gadang wilayah kerja Puskesmas Air Dingin tahun 2016 yang terdata dalam kohort ibu hamil sampai bulan Februari 2016 yang berjumlah 128 orang. Teknik pengambilan sampel dalam penelitian ini adalah menggunakan Total Sampling, yaitu seluruh anggota populasi dijadikan sampel penelitian. Jumlah sampel yang akan diteliti sebanyak 128 orang Ibu hamil di kelurahan Balai Gadang Wilayah Kerja Puskesmas Air Dingin Padang tahun 2016 yang terdata dalam kohort ibu hamil sampai bulan Februari 2016 . Penelitian ini dilakukan di Kelurahan Balai Gadang Wilayah Kerja Puskesmas Air Dingin Padangpada bulan Desember 2015 sampai Mei 2016. Variabel dari penelitian ini terdiri dari variabel independen yaitu tingkat pengetahuan Ibu, peran keluarga, peran kader, peran bidan terhadap Program Perencanaan Persalinan dan Pencegahan Komplikasi $(\mathrm{P} 4 \mathrm{~K})$, serta variabel dependen yaitu penerapan Program Perencanaan Persalinan dan Pencegahan Komplikasi (P4K). Pengolahan data dengan uji statistik Analisis Regresi Linear Ganda atau sering disebut juga Analisis Multiple Regression Linear. Pada analisis ini bentuk adanya pengaruh adalah beberapa variabel bebas terhadap satu variabel terikat dengan komputerisasi untuk menilai kemaknaan digunakan batas kemaknaan nilai $5 \%=$ 0,05 . Bila nilai $\mathrm{p}$ Value $\leq 0,05$ maka variabel independen mempunyai pengaruh yang bermakna terhadap variabel dependen.

\section{HASIL PENELITIAN}

\section{Hasil Analisa Univariat}

Tabel 1 Distribusi Frekuensi Penerapan Program Perencanaan Persalinan dan PencegahanKomplikasi (P4K) Pada Ibu Hamildi Kelurahan Balai Gadang

\begin{tabular}{ccc}
\hline Stiker P4K & F & \% \\
\hline Tidak diterapkan & 85 & 66,4 \\
Diterapkan & 43 & 33,6 \\
Total & $\mathbf{1 2 8}$ & $\mathbf{1 0 0}$ \\
\hline
\end{tabular}


Tabel2 Distribusi Frekuensi Tingkat Pengetahuan Ibu Terhadap Penerapan Program Perencanaan Persalinan dan PencegahanKomplikasi (P4K) di Kelurahan Balai GadangPadang

\begin{tabular}{ccc}
\hline Pengetahuan & F & \% \\
\hline Rendah & 23 & 18,0 \\
Tinggi & 105 & 82,0 \\
Total & $\mathbf{1 2 8}$ & $\mathbf{1 0 0}$ \\
\hline
\end{tabular}

Tabel 3 Distribusi Frekuensi Peran Keluarga Terhadap Penerapan Program Perencanaan Persalinan dan Pencegahan Komplikasi (P4K) di Kelurahan Balai Gadang

\begin{tabular}{ccc}
\hline Peran Keluarga & F & \% \\
\hline Rendah & 74 & 57,8 \\
Tinggi & 54 & 42,2 \\
Total & $\mathbf{1 2 8}$ & $\mathbf{1 0 0}$ \\
\hline
\end{tabular}

Tabel 4 Distribusi Frekuensi Peran Kader Terhadap Penerapan Program Perencanaan Persalinan dan Pencegahan Komplikasi (P4K) di Kelurahan Balai Gadang Padang

\begin{tabular}{ccc}
\hline Peran Kader & F & \% \\
\hline Rendah & 56 & 43,8 \\
Tinggi & 72 & 56,3 \\
Total & $\mathbf{1 2 8}$ & $\mathbf{1 0 0}$ \\
\hline
\end{tabular}

Tabel 5 Distribusi Frekuensi Peran Bidan Terhadap Penerapan Program Perencanaan Persalinan dan Pencegahan Komplikasi (P4K) di Kelurahan Balai Gadang Padang

\begin{tabular}{ccc}
\hline Peran Bidan & f & \% \\
\hline Rendah & 74 & 57,8 \\
Tinggi & 54 & 42,2 \\
Total & $\mathbf{1 2 8}$ & $\mathbf{1 0 0}$ \\
\hline
\end{tabular}

\section{Hasil Analisa Bivariat}

Tabel 6 Hubungan Tingkat Pengetahuan Ibu dengan Penerapan Program Perencanaan Persalinan dan Pencegahan Komplikasi (P4K) di Kelurahan Balai Gadang

\begin{tabular}{|c|c|c|c|c|c|c|}
\hline \multirow{3}{*}{$\begin{array}{l}\text { Tingkat } \\
\text { pengeta } \\
\text { huan }\end{array}$} & \multicolumn{4}{|c|}{$\begin{array}{c}\text { Penerapan/ Pengisian } \\
\text { stiker P4K }\end{array}$} & \multirow{3}{*}{$\begin{array}{c}\text { Tot } \\
\text { al }\end{array}$} & \multirow{3}{*}{$\%$} \\
\hline & \multicolumn{2}{|c|}{$\begin{array}{c}\text { Tidak } \\
\text { diterapkan }\end{array}$} & \multicolumn{2}{|c|}{$\begin{array}{c}\text { Ditarapk } \\
\text { an }\end{array}$} & & \\
\hline & $\mathbf{f}$ & $\%$ & $\mathbf{f}$ & $\%$ & & \\
\hline Rendah & 18 & $\begin{array}{c}78 \\
3\end{array}$ & 5 & $\begin{array}{c}21 \\
7\end{array}$ & 23 & $\begin{array}{c}10 \\
0\end{array}$ \\
\hline Tinggi & 67 & 63,8 & $\begin{array}{l}3 \\
8\end{array}$ & 36,2 & 105 & $\begin{array}{c}10 \\
0\end{array}$ \\
\hline
\end{tabular}

Tabel 7 Hubungan Peran Keluarga dengan Penerapan Program Perencanaan Persalinan dan Pencegahan Komplikasi (P4K) di Kelurahan Balai Gadang

\begin{tabular}{|c|c|c|c|c|c|c|}
\hline \multirow{3}{*}{$\begin{array}{c}\text { Peran } \\
\text { Keluar } \\
\text { ga }\end{array}$} & \multicolumn{4}{|c|}{$\begin{array}{c}\text { Penerapan/ Pengisian } \\
\text { stiker P4K }\end{array}$} & \multirow{3}{*}{$\begin{array}{c}\text { T } \\
\text { ot } \\
\text { al }\end{array}$} & \multirow{3}{*}{$\%$} \\
\hline & \multicolumn{2}{|c|}{$\begin{array}{c}\text { Tidak } \\
\text { diterapkan }\end{array}$} & \multicolumn{2}{|c|}{$\begin{array}{c}\text { Ditarapka } \\
\text { n }\end{array}$} & & \\
\hline & f & $\%$ & $\mathbf{f}$ & $\%$ & & \\
\hline Rendah & 57 & $\begin{array}{c}77, \\
0\end{array}$ & 17 & $\begin{array}{c}23, \\
0\end{array}$ & $\begin{array}{l}7 \\
4\end{array}$ & 100 \\
\hline Tinggi & 28 & 51,9 & 26 & 48,1 & $\begin{array}{l}5 \\
4\end{array}$ & 100 \\
\hline
\end{tabular}

Tabel 8 Hubungan Peran Kader dengan Penerapan Program Perencanaan Persalinan dan Pencegahan Komplikasi (P4K) di Kelurahan Balai Gadang

\begin{tabular}{|c|c|c|c|c|c|c|}
\hline \multirow{3}{*}{$\begin{array}{l}\text { Peran } \\
\text { Kader }\end{array}$} & \multicolumn{4}{|c|}{$\begin{array}{c}\text { Penerapan/ Pengisian } \\
\text { stiker P4K }\end{array}$} & \multirow{3}{*}{$\begin{array}{l}\text { To } \\
\text { tal }\end{array}$} & \multirow{3}{*}{$\%$} \\
\hline & \multicolumn{2}{|c|}{$\begin{array}{c}\text { Tidak } \\
\text { diterapkan }\end{array}$} & \multicolumn{2}{|c|}{$\begin{array}{c}\text { Ditarapka } \\
\text { n }\end{array}$} & & \\
\hline & f & $\%$ & f & $\%$ & & \\
\hline $\begin{array}{c}\text { Renda } \\
\mathrm{h}\end{array}$ & 37 & $\begin{array}{c}66, \\
1\end{array}$ & 19 & 33,9 & 56 & $\begin{array}{c}10 \\
0\end{array}$ \\
\hline Tinggi & 48 & 66,7 & 24 & 33,3 & 72 & $\begin{array}{c}10 \\
0\end{array}$ \\
\hline
\end{tabular}


Tabel 9 Hubungan Peran Bidan dengan Penerapan Program Perencanaan Persalinan dan Pencegahan Komplikasi (P4K) di Kelurahan Balai Gadang

\begin{tabular}{|c|c|c|c|c|c|c|}
\hline \multirow{3}{*}{$\begin{array}{l}\text { Peran } \\
\text { Bidan }\end{array}$} & \multicolumn{4}{|c|}{$\begin{array}{c}\text { Penerapan/ Pengisian } \\
\text { stiker P4K }\end{array}$} & \multirow{3}{*}{$\begin{array}{l}\text { To } \\
\text { tal }\end{array}$} & \multirow[t]{3}{*}{$\%$} \\
\hline & \multicolumn{2}{|c|}{$\begin{array}{c}\text { Tidak } \\
\text { diterapkan }\end{array}$} & \multicolumn{2}{|c|}{ Ditarapkan } & & \\
\hline & $\mathbf{f}$ & $\%$ & $\mathbf{F}$ & $\%$ & & \\
\hline $\begin{array}{l}\text { Ren } \\
\text { dah }\end{array}$ & 54 & $\begin{array}{c}73, \\
0\end{array}$ & 20 & & 7 & 10 \\
\hline Ting & 31 & 57 & 23 & 42,6 & $\begin{array}{c}4 \\
54\end{array}$ & 100 \\
\hline
\end{tabular}

\section{Seleksi Bivariat}

Tabel 10 Analisis Bivariat antara Tingkat Pengetahuan dengan Penerapan P4K

\begin{tabular}{cccc}
\hline & Chi-Square & df & sig. \\
\hline Step 1 Step & 10.250 & 1 & 0.171 \\
Block & 10.250 & 1 & 0.171 \\
Model & 10.250 & 1 & 0.171 \\
\hline
\end{tabular}

Tabel 11 Analisis Bivariat antara Peran Keluarga dengan Penerapan P4K

\begin{tabular}{cccc}
\hline & Chi-Square & $\begin{array}{c}\mathrm{d} \\
\mathrm{f}\end{array}$ & sig. \\
\hline Step 1 Step & 8.855 & 1 & 0.003 \\
Block & 8.855 & 1 & 0.003 \\
Model & 8.855 & 1 & 0.003 \\
\hline
\end{tabular}

Tabel 12 Analisis Bivariat antara Peran Kader dengan Penerapan P4K

\begin{tabular}{cccc}
\hline & Chi-Square & df & sig. \\
\hline Step 1 Step & 0.005 & 1 & 0.944 \\
Block & 0.005 & 1 & 0.944 \\
model & 0.005 & 1 & 0.944 \\
\hline
\end{tabular}

Tabel 13 Analisis Bivariat antara Peran Bidan dengan Penerapan P4K

\begin{tabular}{cccc}
\hline & Chi-Square & $\mathrm{df}$ & sig. \\
\hline Step 1 Step & 3.373 & 1 & 0.066 \\
Block & 3.373 & 1 & 0.066 \\
model & 3.373 & 1 & 0.066 \\
\hline
\end{tabular}

Tabel 14 Hasil Seleksi Bivariat

\begin{tabular}{cc}
\hline Variabel & P value \\
\hline Tingkat Pengetahuan & 0.171 \\
Peran Keluarga & 0.003 \\
Peran Kader & 0.944 \\
Peran Bidan & 0.066 \\
\hline
\end{tabular}

\section{Hasil Analisis Multivariat}

Tabel 15 Pengaruh Variabel Tingkat Pengetahuan, Peran Kelurga, Peran Bidan terhadap Penerapan P4K

\begin{tabular}{|c|c|c|c|c|c|c|c|c|}
\hline & \multirow{2}{*}{ B } & \multirow{2}{*}{ S.E. } & \multirow{2}{*}{ Wald } & \multirow{2}{*}{$\begin{array}{l}d \\
f\end{array}$} & \multirow{2}{*}{ Sig. } & \multirow{2}{*}{$\begin{array}{l}\operatorname{Exp} \\
\text { (B) }\end{array}$} & \multicolumn{2}{|c|}{$\begin{array}{l}95 \% \text { CI for } \\
\operatorname{Exp}(\mathrm{B})\end{array}$} \\
\hline & & & & & & & $\begin{array}{l}\text { Low } \\
\text { er }\end{array}$ & $\begin{array}{l}\text { Uppe } \\
\text { r }\end{array}$ \\
\hline Peng & 0,5 & 0,5 & 0,8 & & 0,3 & 1,7 & 0,5 & 5,3 \\
\hline etanu & 47 & 79 & 91 & & 45 & 28 & 55 & 80 \\
\hline Kelu & 1,1 & 0,4 & 8,6 & $\begin{array}{l}1 \\
1\end{array}$ & 0,0 & 3,2 & 1,4 & 7,2 \\
\hline arga & 87 & 04 & 35 & 1 & 03 & 76 & 85 & 30 \\
\hline Bida & 0,8 & 0,4 & 4,2 & 1 & 0,0 & 2,3 & 1,0 & 50 \\
\hline $\mathrm{n}$ & 36 & 04 & 95 & & 38 & 08 & 46 & 89 \\
\hline
\end{tabular}

\section{Uji Interaksi}

Tabel 16 Hasil Uji Interaksi Variabel Peran Keluarga dan Peran Bidan

\begin{tabular}{cccc}
\hline & $\begin{array}{c}\text { Chi- } \\
\text { Square }\end{array}$ & df & sig. \\
\hline Step 1 Step & 14,177 & 3 & 0.003 \\
Block & 14,177 & 3 & 0.003 \\
Model & 14,177 & 3 & 0.003 \\
\hline
\end{tabular}

Tabel 17 Hasil Akhir Analisis Multivariat

\begin{tabular}{|c|c|c|c|c|c|c|c|c|}
\hline & \multirow[b]{2}{*}{ B } & \multirow{2}{*}{ S.E. } & \multirow{2}{*}{ Wald } & \multirow[t]{2}{*}{$d$} & \multirow{2}{*}{ Sig. } & \multirow{2}{*}{$\begin{array}{l}\text { Exp } \\
\text { (B) }\end{array}$} & \multicolumn{2}{|c|}{$\begin{array}{l}95 \% \text { CI for } \\
\operatorname{Exp}(B)\end{array}$} \\
\hline & & & & & & & $\begin{array}{c}\text { Low } \\
\text { er }\end{array}$ & $\begin{array}{l}\text { Uppe } \\
\mathrm{r}\end{array}$ \\
\hline Pen & 0,5 & 0,5 & 0,8 & 1 & 0,3 & 1,7 & 0,5 & 5,3 \\
\hline etah & 47 & 79 & 91 & 1 & 45 & 28 & 55 & 80 \\
\hline an & 1,1 & 0,4 & 8,6 & 1 & 0,0 & 3,2 & 1,4 & 7.2 \\
\hline
\end{tabular}




\begin{tabular}{ccccccc}
\hline Kelu & 87 & 04 & 35 & 03 & 76 & 85 \\
arga & 0,8 & 0,4 & 4,2 & 0,0 & 2,3 & 1,0 \\
Bida & 36 & 04 & 95 & 38 & 08 & 46 \\
$\mathrm{n}$ & & & & & & \\
\hline
\end{tabular}

\section{PEMBAHASAN}

Dari tabel 1 dapat dilihat bahwa responden yang tidak menerapkan/ mengisi stiker P4K sebanyak 85 responden $(66,4 \%)$. Hasil penelitian ini sangat jauh berbeda dengan penelitian yang dilakukan oleh Mikrajab dan Tety yang dilakukan di kota Modjokerto dimana pemasangan stiker $\mathrm{P} 4 \mathrm{~K}$ telah mencapai 94,0\%. ${ }^{7}$ Salah satu tujuan dari P4K dengan stiker adalah terdatanya status ibu hamil dan terpasangnya stiker P4K disetap rumah Ibu hamil yang memuat semua informasi tentang lokasi tempat tinggal Ibu hamil, identitas Ibu hamil, taksiran persalinan, penolong persalinan, pendamping persalinan, fasilitas tempat persalinan, calon donor darah, serta transportasi yang akan digunakan dan pembiayaan persalinan. Peneliti berasumsi penggunaan stiker $\mathrm{P} 4 \mathrm{~K}$ dapat secara langsung memberikan gambaran kepada ibu tentang bagimana persalinan yang akan dihadapi ibu dan telah tersedia sarana yang dibutuhkan jika ibu mengalami masalah dalam persalinan nanti sehingga ibu akan mendapatkan pelayanan yang cepat dan tepat. Angka penerapan P4K di Balai Gadang 33,6 \% masih jauh dari target yang diharapkan yaitu $100 \%$ sehingga penerapan $\mathrm{P} 4 \mathrm{~K}$ harus dapat di tingkatkan dengan program sadar diri oleh ibu hamil.

Berdasarkan tabel 2 ditemukan 23 responden $(18,0 \%)$ memiliki pengetahuan rendah tentang Program PerencanaanPersalinan dan PencegahanKomplikasi (P4K). Hasil penelitian ini sejalan dengan hasil penelitian Rachmawati dan Devi yang menunjukkan bahwa sebagian besar responden mempunyai pengetahuan baik sebanyak $21 \mathrm{ibu}$ hamil (46,7\%), dan sebagian kecil responden mempunyai pengetahuan kurang sebanyak 11 ibu hamil $(24,4 \%)$. Pada tingkatan pengetahuan yang paling tinggi yaitu tingkatan evaluasi yang berkaitan dengan kemampuan seseorang untuk melakukan justifikasi atau penilaian terhadap suatu objek tertentu. Penilaian ini dengan sendirinya didasarkan pada suatu kriteria yang ditentukan sendiri atau norma-norma yang berlaku di masyarakat. ${ }^{8}$ Peneliti berasumsi bahwa pengetahuan ibu tentang program perencanaan persalinan dan pencegahan komplikasi yang direalisasikan dengan menggunakan stiker harus barada pada tahap evaluasi sehingga ibu sadar dan mampu melakukan penilaian
Bentang tujuan, manfaat, dan pentingnya program forencanaan persalinan dan pencegahan komplikasI. 89 Tabel 3 menunjukan bahwa terdapat 74 responden $(57,8 \%)$ dengan peran keluarga rendah terhadap penerapan Program Perencanaan Persalinan dan Pencegahan Komplikasi (P4K). Hasil ini sejalan dengan penelitian yang dilakukan oleh Puspita dkk dengan hasil peran suami paling banyak pada kategori tidak siaga $51,4 \%$ dan siaga $48,5 \%$. ${ }^{9}$ Dari data tersebut dapat diketahui bahwa mayoritas dari keluarga responden tidak memberikan peran yang seharusnya dapat ia berikan seperti suami dan keluarga paham tentang bahaya persalinan, adanya rencana persalinan aman (yang disepakati antara ibu hamil,suami dan keluarga, dengan bidan), adanya rencana alat kontrasepsi setelah melahirkan (yang disepakati Ibu hamil, suami dan keluarga, dengan bidan), dan adanya dukungan sukarela dari keluarga dalam perencanaan persiapan persalinan ibu hamil dalam hal biaya, transportasi, donor darah untuk proses persalinan termasuk menghadapi kegawatdaruratan Ibu hamil, Ibu bersalin dan bayi baru lahir. Peneliti berasumsi bahwa peran keluarga masih rendah karena kurangnya pengetahuan keluarga terhadap P4K dan pada penyuluhan kesehatan ibu dan anak keluarga kurang ikut serta sehingga informasi kesehatan ibu dan anak bagi kelurga perlu ditingkatkan.

Dari tabel 4 dapat di lihat bahwa sebanyak 56 responden $(43,8 \%)$ memberikan hasil bahwa peran kader rendah terhadap penerapan Program Perencanaan Persalinan dan Pencegahan Komplikasi (P4K). Hasil penelitian ini sedikit berbeda dengan penelitian yang dilakukan oleh Mikrajab dan Tety yang menunjukkan bahwa secara keseluruhan, peran kader dalam kegiatan P4K di Posyandu terkait penyuluhan dan target telah berjalan dengan baik. Peran kader kesehatan yang telah dilaksanakan adalah pemeriksaan kehamilan telah mencapai 100\%; pemasangan stiker P4K telah mencapai 94,0\%; Penyimpanan buku KIA oleh Ibu hamil telah mencapai $88,1 \%$; penyuluhan pada dukun bayi baru mencapai 73,1\%; PWS bersama bidan baru mencapai 59,7\%; belum memberikan buku KIA kepada ibu hamil masih 25,4\%; dan merujuk ke Puskesmas mencapai $62,7 \%$. Meskipun demikian, terdapat beberapa aspek peran kader kesehatan yang perlu ditingkatkan intensitasnya yaitu penyuluhan kepada dukun bayi, dan pemanfaatan buku KIA serta penerapan sistem rujukan berjenjang pelayanan Kesehatan maternal dalam P4K. Kader kesehatan adalah tenaga sukarela yang dipilih oleh masyarakat dan bertugas mengembangkan masyarakat. Dalam hal ini kader juga disebut sebagai penggerak atau promotor masyarakat. ${ }^{10}$ Kader kesehatan mempunyai 
peran besar dalam upaya meningkatkan kemampuan masyarakat menolong dirinya untuk mencapai derajat kesehatan yang optimal. Sehubungan dengan itu peneliti berasumsi bahwa peran kader masih kurang merata karena ada ibu hamil yang mendapatkani informasi kesehatan secara baik dan ada ibu hamil yang kurangmendapat informasi kesehatan. Adanya peran kader dalam masyrakat dapat mewujudkan masyarakat yang peduli kesehatan.

Berdasarkan tabel 5 tentang peran bidan dalam Penerapan Program PerencanaanPersalinan dan Pencegahan Komplikasi (P4K) terdapat 74 responden $(57,8 \%)$ menyatakan peran bidan negatif. Sejalan dengan hasil penelitian yang dilakukan oleh Rinayati dkk yang menunjukan bahwa sebagian besar kinerja $(53, \%)$ cukup, terutama pada operasionalisasi P4K namun meskipun demikian tetap diharapkan bahwa pemerintah mengikutsertakan bidan desa ke pelatihan program $\mathrm{P} 4 \mathrm{~K}$, membuat SOP pelaksanaan program P4K. ${ }^{11}$ Bidan di desa berfungsi untuk memberikan pelayanan kesehatan khususnya pelayanan KIA termasuk KB di wilayah desa tempat tugasnya. Bidan melakukan penyuluhan dan konseling pada ibu hamil dan keluarga mengenai: Tanda-tanda persalinan, tanda bahaya persalinan dan kehamilan, kebersihan pribadi dan lingkungan, kesehatan dan gizi, perencanaan persalinan ( bersalin dibidan, menyiapkan transportasi, menyiapkan biaya, menyiapkan calon donor darah), perlunya inisiasi menyusu dini dan ASI ekslusif, KB pasca persalian. ${ }^{12}$ Peneliti berasumsi bahwa diharapkan bahwa pemerintah mengikutsertakan bidan desa ke pelatihan program $\mathrm{P} 4 \mathrm{~K}$, membuat SOP pelaksanaan program P4K merupakan masukan yang baik untuk meningkatkan kinerja serta peran bidan dalam penerapan program perencanaan persalinan dan pencegahan komplikasi ( $\mathrm{P} 4 \mathrm{~K})$ sebagai suatu program yang diharapkan dapat meningkatkan pelayanan kesehatan ibu dan anak serat menekan angka kematian ibu (AKI) dan angka kematian bayi (AKB).

Bardasarkan tabel 6 dapat dilihat bahwa dari 23 responden yang berpengetahuan rendah terdapat 18 responden $(78,3 \%)$ yang tidak menerapkan P4K sedangkan dari 105 responden yang berpengetahuan tinggi terdapat 67 responden $(63,8 \%)$ tidak menerapkan P4K. Pada hasil uji statistik didapatkan $p$ value $=0,171$ ( $p$ value $\leq 0,25)$ sehingga dapat dikatakan terdapat hubungan yang bermakna antara tingkat pengetahuan dengan penerapan P4K. Hasil penelitian ini sejalan dengan penelitian Rahmawati dan Devi yang menunjukan bahwa mayoritas tingkat pengetahuan ibu hamil baik yaitu sebanyak 21 orang (46,7\%), sebagian besar ibu hamil menggunakan stiker P4K yaitu sebanyak 27 orang $(60 \%)$. Hasil uji statistik dengan taraf signifikan 0,05 didapatkan hasil $\mathrm{p}=0,000$ ( $\mathrm{p}$ value $<\alpha)$ yang berarti ada hubungan yang bermakna antara tingkat pengetahuan dengan penggunaan stiker $\mathrm{P} 4 \mathrm{~K}$. Berdasarkan penelitian yang dilakukan oleh Pertiwi (2013) diketahui bahwa pengetahuan Ibu hamil tentang P4K akan mempengaruhi sikap Ibu hamil terhadap obyek yang sama, sehingga semakin baik pengetahuan Ibu hamil tentang P4K sebagai upaya pencegahan komplikasi kehamilan maka akan semakin positif pula sikap Ibu hamil terhadap $\mathrm{P} 4 \mathrm{~K}$ tersebut meskipun tidak selamanya yang memiliki pengetahuan baik memiliki sikap positif dan sebaliknya tidak selalu yang memiliki pengetahuan kurang memiliki sikap negatif. ${ }^{13}$ Peneliti berasumsi bahwa dengan meningkatnya pengetahuan ibu tentang $\mathrm{P} 4 \mathrm{~K}$ maka ibu hamil akan mampu menerapkan P4K secara maksimal sehingga diperlukan adanya penyuluhan secara merata tentang Program Perencanaan Persalinan dan Pencegahan Komplikasi kepada seluruh ibu hamil.

Dari tabel 7 dapat diketahui dari 74 responden dengan peran keluarga rendah terdapat 57 responden $(77,0 \%)$ tidak menerapkan $\mathrm{P} 4 \mathrm{~K}$ sedangkan dari 54 responden dengan peran keluarga tinggi terdapat 28 responden $(51,9 \%)$ tidak menerapkan P4K. Pada hasil uji statistik didapatkan $p$ value $=0,003$ ( $p$ value $\leq 0,25$ ) sehingga dapat dikatakan terdapat hubungan yang bermakna antara peran keluarga dengan penerapan P4K. Dalam melaksanakan program Gerakan Sayang Ibu (GSI) maka diperlukan partisipasi suami sebagai suami siaga diantaranya: Mempelajari gejala komplikasi pada kehamilan seperti darah tinggi, kaki bengkak, perdarahan, konsultasi dalam melahirkan, infeksi dan sebagainya; Menyiapkan biaya transportasi; Melakukan rujukan ke fasilitras kesehatan yang lebih lengkap sedini mungkin bila terjadi hal- hal yang menyakut kesehatan kehamilan dan kesehatan janin misalnya perdarahan; Menentukan tempat persalinan (fasilitas kesehatan) sesuai dengan kemampuan dan kondisi daerah masing - masing. Hasil penelitian Astuti (2008) menemukan bahwa kematian ibu bersalin disebabkan terjadinya keterlambatan dalam merujuk ke rumah sakit yang terdiri dari keterlambatan dalam mengambil keputusan setuju merujuk dari pihak keluarga, keterlambatan dalam mengenali risiko tinggi ibu bersalin baik oleh bidan dan/atau keluarga, keterlambatan dalam mencari bidan yang bersedia menolong persalinan, keterlambatan dalam mencari transportasi, dan keterlambatan dalam mengambil keputusan merujuk atau membawa ke rumah sakit yang disebabkan adat istiada. ${ }^{14}$ Peneliti berasumsi bahwa dengan adanya partisipasi dari suami dan keluarga diharapkan ibu lebih termotivasi dan mendapat dukungan dalam menerapkan Program Perencanaan Persalinan dan Pencegahan Komplikasi. 
Untuk itu diperlukan adanya konseling pada keluarga tentang Program Perencanaan Persalinan dan Pencegahan Komplikasi agar ibu beserta keluarga bersama-sama menerapkan $\mathrm{P} 4 \mathrm{~K}$ dan melakukan perencanaan persalinan semaksimal mungkin.

Tabel 8 menunjukkan bahwa dari 56 responden dengan peran kader rendah terdapat 37 responden $(66,1 \%)$ tidak menerapkan P4K sedangkan dari 72 responden dengan peran kader tinggi terdapat 28 responden $(66,7 \%)$ tidak menerapkan P4K. Pada hasil uji statistik didapatkan $p$ value $=0,994$ ( $p$ value $>0,25$ ) sehingga dapat dikatakan tidak terdapat hubungan yang bermakna antara peran kader dengan penerapan P4K. Hasil ini berbeda dengan hasil penelitian oleh Mikrajab dan Tety yang menunjukkan bahwa peran kader kesehatan yang telah dilaksanakan adalah pemeriksaan kehamilan telah mencapai $100 \%$; pemasangan stiker $\mathrm{P} 4 \mathrm{~K}$ telah mencapai 94,0 \% sedangkan pada penelitian ini hanya 43,3\% yang melakukan penerapan P4K. Peran kader dalam program $\mathrm{P} 4 \mathrm{~K}$ dilakukan kader dengan cara: Membantu memotivasi perencanaan persalinan (bersalin dimana, oleh siapa, transportasi, biaya persalinan, donor darah dan KB pasca persalinan); Melakukan kunjungan rumah untuk memotivasi perencanaan persalinan. ${ }^{15}$ Terhadap hasil ini peneliti berasumsi bahwa adanya perbedaan hasil peran kader pada penelitian ini dan sebelumnya di karenakan kondisi wilayah pada penelitian ini berada pada dataran tinggi dan wilayah yang luas sehingga kinerja dari kader kurang maksimal dan kurang merata.

Berdasarkan tabel 9 diketahui bahwa dari 74 responden dengan peran bidan rendah terdapat 54 responden $(73,0 \%)$ tidak menerapkan $\mathrm{P} 4 \mathrm{~K}$ sedangkan dari 54 responden dengan peran bidan tinggi terdapat 31 responden $(57,4 \%)$ tidak menerapkan P4K. Pada hasil uji statistik didapatkan $p$ value $=0,066$ ( $p$ value $\leq 0,25$ ) sehingga dapat dikatakan terdapat hubungan yang bermakna antara peran bidan dengan penerapan P4K. Dalam penelitian yang dilakukan oleh Sokhiyatun menyimpulkan bahwa indikator keberhasilan yang dipahami bidan bahwa stiker harus terpasang di setiap rumah ibu hamil yang ada di wilayahnya. Bidan desa melakukan aspek perencanaan persalinan cukup baik, serta melakukan koordinasi dan komunikasi melalui sosialisasi dan pertemuan rutin. ${ }^{16}$ Peran bidan dalam program $\mathrm{P} 4 \mathrm{~K}$ dapat yaitu dengan mendukung upaya partisipasi aktif forum peduli KIA dan dukun untuk melaksanakan komponen-komponen $\mathrm{P} 4 \mathrm{~K}$ dengan stiker di wilayah tersebut melalui pertemuan rapat koodinasi tingkat desa (Pedoman P4K dengan Stiker Depkes RI, 2009). Berdasarkan penelitian yang telah dilakukan dengan meninjau kembali teori yang telah ada maka peneliti berasumsi bahwa peran bidan dalam penerapan $\mathrm{P} 4 \mathrm{~K}$ dapat memeberikan dampak yang baik terhadap P4K dengan melibatkan seluruh aspek dari forum peduli KIA yang termasuk didalamnya adalah partisipasi aktif dari suami siaga.

Dari tabel 4.14 diketahui bahwa variabel yang dapat dimasukkan kedalam analisis multivariat adalah variabel yang mempunyai nilai p value $\leq 5,25$. Pada tabel tersebut didapatkan tiga variabel yang memenuhi syarat analisis multivariat yaitu tingkat pengetahuan, peran keluarga, peran bidan. Kemudian dilakukan analisis multivariat ketiga variabel tersebut. Untuk mengetahui apakah variabel tersebut mempunyai pengaruh terhadap penerapan $\mathrm{P} 4 \mathrm{~K}$ maka variabel harus mempunyai $p$ value $\unlhd), 05$. Pada tabel diketahui terdapat dua variabel yang mempunyai pengaruh terhadap penarapan $\mathrm{P} 4 \mathrm{~K}$ yaitu peran keluarga dengan $\mathrm{p}$ value $=0,003$ dan peran bidan dengan $p$ value $=0,038$. Artinya secara statistik peran keluarga dan peran bidan akan mempengaruhi ibu hamil dalam menerapkan $\mathrm{P} 4 \mathrm{~K}$, sedangkan tingkat pengetahuan secara statistik tidak mempunyai pengaruh dalam penerapan P4K. Namun karena variabel tingkat pengetahuan secara substansi dianggap penting, maka variabel peran bidan tetap digunakan dalam melakukan analisis pengaruh bersama-sama.

Pada tabel 4.17 variabel peran keluarga hasil analisis menunjukkan Exp B : 3,276, p : 0,003, p $\leq$ 0,05 . Hasil ini berarti bahwa peran keluarga yang posisif akan memberikan dampak 3,276 kali pada ibu hamil untuk menerapkan $\mathrm{P} 4 \mathrm{~K}$, sedangkan peran keluarga yang negatif akan memberikan dapak pada ibu hamil 3,276 kali untuk tidak menerapkan P4K. Peneliti berasumsi bahwa keluarga berperan penting dalam penerapan P4K karena peran keluarga secara intrinsik akan mempengaruhi ibu untuk menerapkan $\mathrm{P} 4 \mathrm{~K}$. Kemudian pada variabel peran bidan didapatkan hasil Exp B : 2,308 p : 0,038, p $\leq 0,05$ yang artinya peran bidan yang positif akan mengakibatkan ibu hamil 2,308 kali akan menerapkan P4K, sedangkan peran bidan yang negatif akan mengakibatkan 2,308 kali ibu hamil tidak akan menerapkan P4K. Peneliti berasumsi bahwa bidan sebagai pendidik dan advokasi harus memberikan pengetahuan pada ibu hamil dan keluarga tentang P4K agar penerapan P4K dapat ibu hamil lakukan dengan dukungan keluarga.

Pada tabel 4.17 didapatkan hasil analisis variabel tingkat pengetahuan menunjukkan bahwa Exp B : 1,728, p : 0,345, p > 0,05. Hasil ini berarti, ibu hamil yang memiliki pengetahuan tinggi akan menerapkan P4K 1,728 kali lebih baik, sedangkan ibu hamil dengan tingkat pengetahuan rendah 1,728 kali tidak akan menerapkan P4K. Semakin tinggi tingkat pengetahuan seseorang maka akan semakin baik orang tersebut menerapkan seseuatu atau 
mengaplikasikan sesuatu. Hai ini sesuai dengan teori Notoatmodjo.Aplikasi diartikan apabila orang orang yang telah memahami objek yang dimaksud dapat menggunakan atau mengaplikasikan prinsip yang diketahui tersebut pada situasi yang lain.

Pada tabel 4.16 menunjukan hasil uji interaksi dari variabel-variabel yang secara signifikan berpengaruh terhadap penerapan $\mathrm{P} 4 \mathrm{~K}$. Pada tabel tersebut didapatkan nilai $\mathrm{p}$ value $=0.003$, $\mathrm{p}$ value $\leq$ 0,05 yang berarti ada interaksi yang signifikan antara peran keluarga dengan peran bidan.

Berdasarkan tabel 4.17 diketahui bahwa variabel yang paling besar pengaruhnya terhadap penerapan $\mathrm{P} 4 \mathrm{~K}$ adalah variabel peran keluarga dengan Exp B : 3,276 p : 0,003, p $\leq 0,05$. Maka diharapkan kepada seluruh unsur kesehatan agar dapat memberikan pelayanan kesehatan yang dapat meningkatkan peran serta keluarga dalam menerapkan P4K sebagai upaya untuk menyukseskan Program Perencanaan Persaliana dan Pencegahan Komplikasi yang bertujuan untuk menurunkan Angka Kematian Ibu (AKI) dan Angka Kematian Bayi (AKB) di Indonesia.

\section{KESIMPULAN}

Penerapan P4K di kelurahan Balai Gadang masih rendah hal ini terlihat dari jumlah ibu hamil yang menerapkan P4K kurang dari separoh dari jumlah ibu hamil yang diteliti. Mayoritas ibu hamil di kelurahan Balai Gadang memiliki pengetahuan tinggi tentang $\mathrm{P} 4 \mathrm{~K}$ namun hal tersebut belum sejalan dengan penerapan $\mathrm{P} 4 \mathrm{~K}$ yang masih tergolong rendah.

Peran keluarga dalam menerapkan $\mathrm{P} 4 \mathrm{~K}$ di kelurahan Balai Gadang terlihat kurang baik dimana peran negatif terlihat lebih dominan daripada peran positif keluarga dalam menerapkan P4K.Kader memiliki yang cukup baik di kelurahan Balai Gadang, dimana peran positif lebih besar dari peran yang bersifat negatif terhadap penerapan P4K.Dikelurahan Balai Gadang peran Bidan tampak sedikit kurang baik karena mayoritas Bidan memiliki peran yang negatif terhadap penerapan P4K.Terdapat hubungan yang signifikan antara tingkat pengetahuan terhadap penerapan P4K di kelurahan Balai Gadang .Terdapat hubungan yang signifikan antara peran keluarga terhadap penerapan P4K .Tidak terdapat hubungan yang signifikan antara peran bidan terhadap penerapan P4K di kelurahan Balai Gadang .Terdapat hubungan yang signifikan antara peran bidan terhadap penerapan P4K di kelurahan Balai Gadang.Peran keluarga dan peran bidan mempengaruhi ibu hamil dalan menerapkan Program Perencanaan Persalinan dan Pencegahan Komplikasi di kelurahan Balai Gadang.

\section{ACKNOWLEDGMENT}

Peneliti mengucapkan terima kasih kepada KEMENRISTEK DIKTI yang telah memberikan hibah penelitian dosen pemula sehingga peneliti dapat melakukan TRI DHARMA Perguruan Tinggi. Kepada Pimpinan Puskesmas Air Dingin yang telah memberikan izin kepada peneliti untuk melakukan penelitian di wilayah kerja Balai Gadang.

\section{DAFTAR PUSTAKA}

[1] Profil Kesehatan Kota Padang Tahun 2014

[2] Survei Demografi Kesehatan Indonesia Tahun 2012

[3] Profil Kesehatan RI Tahun 2013

[4] Runjati . 2010 . Asuhan Kebidanan Komunitas . Jakarta : EGC

[5] Rahmawati, Ita dan Devi Rosita . 2011. Hubungan Tingkat Pengetahuan Ibu Hamil tentang P4K dengan Penggunaan Stiker P4K di Desa Mijen Kecamatan Kaliwungu Kabupaten Kudus. Jurnal kesehatan dan Budaya : Jawa Tengah

[6] Profil Kesehatan RI Tahun 2014

[7] Mikrajab, Muhammad Agus dan Tety Rachmawaty . 2011 . Peran Kader Kesehatan dalam Program Perencanaan Persalinan dan Pencegahan Komplikasi pada Ibu Hamil di Posyandu di Kota Mojokerto. Badan Penelitian dan Pengembangan Kesehatan, Kemenkes RI: Jawa Timur

[8] Notoatmodjo, Soekidjo . 2010 . Promosi Kesehatan Teori dan Aplikasi . Jakarta : Rajawali Pers

[9] Puspita, Mike Ahyu dkk. 2014. Hubungan Antara Peran Suami Siaga dengan Frekuensi Kunjungan Antenatal Care (Anc) pada Ibu Hamil Trimester III di Kelurahan Pojoksari Kecamatan Ambarawa Kabupaten Semarang. STIKES Ngudi Waluyo Ungaran : Semarang

[10] Yulifah, Rita dan Tri Johan . 2013 . Asuhan Kebidanan Komunitas . Jakarta : Salemba Medika

[11] Rinayati, dkk. 2012. Studi Deskriptif Kinerja Bidan Desa dalam Melaksanakan Program Perencanaan Persalinan dan Pencegahan Komplikasi (P4K) di Kabupaten Batang. STIKES Widya Husada: Semarang 
[12] Pedoman Program Perencanaan Persalinan dan Pencegahan Komplikasi (P4K) Dengan Stiker . 2009 . Departemen Kesehatan Republik Indonesia

[13] Pertiwi, Dina . 2013 . Hubungan Pengetahuan dan Sikap Ibu Hamil tentang Program Perencanaan Persalinan dan Pencegahan Komplikasi (P4K) Sebagai Upaya Pencegahan Komplikasi Kehamilan di kelurahan Kutambaru Kabupaten Langkat . Medan : Universitas Sumatera Utara

[14] Astuti, Sri Puji. 2008. Pola Pengambilan Keputusan Keluarga dan Bidan dalam Merujuk Ibu Bersalin ke Rumah Sakit pada Kasus Kematian Ibu Di Kabupaten Demak. Universitas Diponegoro: Semarang

[15] Maryunani, Anik dan Eka Puspita . 2013. Program Perencanaan Persalinan dan Pencegahan Komplikasi (P4K) . Jakarta : Trans Info Media

[16] Sokhiyatun. 2012. Pelaksanaan Program Perencanaan Persalinan dan Pencegahan Komplikasi (P4K) Ditinjau dari Aspek Bidan Desa sebagai Pelaksana di Kabupaten Jepara. Universitas Diponegoro: Jepara

[17] Sujiyatini, dkk, Asuhan kebidanan II (persalinan). Yogyakarta : Rohima Press, 2011

[18] Widyatun, D, Manajemen Aktif Kala III. (http://bidandiah.blogspot.com/2012/04/manaje men-aktif-kala-iii.html), 2012

[19] Varney, H, dkk, Buku Ajar Asuhan Kebidanan. Jakarta : EGC, 2008

[20] Oxorn, H, Ilmu Kebidanan : Patologi \& Fisiologi Persalinan. Yogyakarta : Yayasan Essentia Medica, 2010 